\title{
Development of Experimental Setup for Measuring Thermal Conductivity Characteristics of Soil
}

\author{
GUL MUHAMMAD*, AMANULLAH MARRI*, AND ABDUL MAJEED SHAR** \\ RECEIVED ON 27.07.2017 ACCEPTED ON 13.11.2017
}

\begin{abstract}
Thermal conductivity displays a key role in design of engineering structures where, thermal stresses resulting from heat and temperatures are of concern. Significant efforts were made to measure the thermal conductivity of different materials. For thermal conductivity characterization of soil samples it is essential to have very flexible set-up. Hence, this paper provides details about indigenously developed experimental setup for thermal conductivity measurement. The design of this newly developed setup is based on the basic principle of steady state heat flow. This experimental setup is designed in order to measure the thermal conductivity of various materials such as soils, rocks, concrete and any type of unbonded and bonded materials. In this paper, initially the theoretical background of the measurement techniques and the principle of heat flow are described, followed by design description and working procedure. The design has been kept very simple, adjustable for varying type and size of specimens and easy to operate with excellent level of accuracy as evident from system calibration. The accuracy and precision of the newly developed setup was verified by testing reference materials of known thermal conductivity and in the test results a high correlation coefficient $\left(R^{2}=0.999\right)$ between experimental data and fitting curve was achieved.
\end{abstract}

Key Words: Experimental Setup, Thermal Conductivity, Guarded Heat Flow, Steady State Method, Wheat Straw, Lime.

\section{INTRODUCTION}

$\mathrm{T}$ The thermal properties of soil are helpful in understanding the energy partitioning in the soil profile. The thermal conductivity/resistivity has significant applications in geotechnical engineering, agricultural engineering and climatology. The geothermal technology which is a major source of clean energy is mainly based on the thermal properties of soil. The thermal conductivity exhibits an important role in the design of engineering structures where thermal stresses and temperature are of concerns [1]. It is more accurately related with the transmission of heat through the soil by radiation, conduction and convection.

To date, a variety of measurement techniques have been developed for the determination thermal characteristics of soil. For thermal characterization of bulk material, steady state and transient flow principals are generally applied [2-3]. For instance, Guarded heat flow meter, works on the

\footnotetext{
Authors E-Mail: (gulmohammad@neduet.edu.pk, amanmuri@neduet.edu.pk,majeed@neduet.edu.pk)

* Department of Civil Engineering, NED University of Engineering \& Technology, Karachi.

** Department of Petroleum Engineering, NED University of Engineering \& Technology, Karachi.
}

This is an open access article published by Mehran University Research Journal of Engineering and Technology, Jamshoro under the CC by 4.0 International License. 
principle of steady-state method and hot-wire/line heat source apparatus works on the principle of transient heat flow [3]. Each of these methods has certain advantages and limitations.

The thermal properties of soil and other composite materials alters due to modifications of their properties such as the emerging soil stabilization technology which has a significant role in the ground improvement where different soil stabilizing agents are used [4]. Therefore, it is essential to have an experimental setup with the help of that the thermal conductivity characteristics of undisturbed, remolded and composite materials can be determined.

The present experimental setup is based on the basic principal of guarded heat flow meter as per ASTM Standard (ASTM E1530-11) with the flexibility of using indigenous development technique. The experimental setup designed is based on the locally available materials and skills, low instrument cost and maintenance and is easy to operate.

In addition, the current experimental setup can easily be modified and optimized for testing samples of different materials; such as, soil, concrete, ceramic, cemented materials and un-cemented materials etc. Different shape of samples can also be tested; such as, cylindrical and cubical shapes. Various sizes of samples ranging from 10$100 \mathrm{~mm}$ thickness and 36-140 mm diameter may be used for testing.

\section{$1.1 \quad$ Theoretical Background}

The thermal conductivity of soil may be defined as the quantity of heat transmitted through the unit length of substance per unit cross-section, per unit time under a unit temperature gradient. Thermal properties are of great interest to designing of many of the problems associated with geotechnical engineering. Several studies have been conducted to study the impact of various parameters on the thermal performance of the insulating materials [5-7]. The heat flow that occurs due to three processes i.e. conduction, convection, and radiation; their rate of flow through material could be delayed by applying insulating materials [8]. Thermal insulation materials decrease the flow of heat within the building due to their low thermal conductivity [8]. The thermal conductivity in these applications is the most challenging task faced by the civil engineering professionals; whereas, temperature changes across the material play a significant role to affect the conductivity characteristics.

Factors that affect the rate of heat flow include the conductivity, temperature difference, sample thickness and the contact area of the sample. The thermal properties of the soil are also affected by the density and water content of the specimen [13]. From material to material, the thermal conductivity or resistivity characteristics vary to make these good conductors or an insulator [9]. Moreover, the factors responsible to affect the rate of transfer of heat conduction from one medium to another medium in any material consist of the material conductivity, for instance, some materials are highly conductive and some are less conductive. Moreover, the material size and thickness also matters. The effect of the sizes was explored by [10-12].

The heat flow mechanism mainly depends on the temperature gradient and its transfer through a medium either by conduction, convection or radiation. The heat flow mechanism is shown in Fig. 1(a-b) where it is being transferred from the heat source to the heat sink by the conduction process [14].

The amount of heat energy (Q) transferred across a material is directly proportional to the area of cross section (A) and the temperature gradient $\Delta \mathrm{T}$ and inversely proportional to the sample thickness (L) and can be expressed as given in Equation (1), and therefore, the coefficient of thermal conductivity $(\mathrm{K})$ can be expressed as shown in Equation (2).

Mehran University Research Journal of Engineering \& Technology, Volume 37, No. 4, October, 2018 [p-ISSN: 0254-7821, e-ISSN: 2413-7219] 
$Q=\frac{k A \Delta T}{L}$

$K=\frac{Q L}{A \Delta T}$

Where in Equations (1-2) Q is heat energy, $\mathrm{L}$ is sample thickness, $\Delta \mathrm{T}$ is the temperature gradient, $\mathrm{K}$ is the coefficient of thermal conductivity and $\mathrm{A}$ is the area of cross section.

Guarded heat flow is the most effective method which is usually used for the determination of thermal conductivity of materials [3]. Guarded heat flow technique is more appropriate to characterize low thermal conductivity materials for building insulation materials. It works on the principle of steady-state transfer of heat through the known thickness of the test specimen between a hot plate and a cold plate. However, there are certain limitations to the equipment that is the longer measurement time is needed to perform the experiment; hence it takes a longer time to achieve a steady-state temperature gradient [15]. Other potential error in measurements might cause due to the improper contact between the surfaces of the test specimen.

\section{Heat Source}

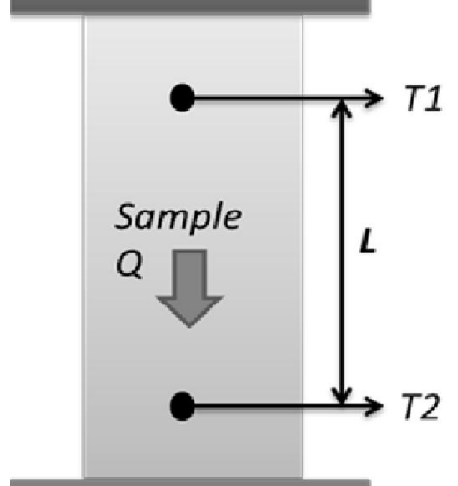

\section{Heat Sink}

The list of the most commonly used thermal conductivity measurement methods is provided in Table 1 that can be divided into steady-state or transient methods. All thermal conductivity measurement methods with the advantages and limitations are also provided in the Table, which includes the equipment operating temperature ranges and the associated uncertainties. Some of these methods are suitable for measurement for particular materials especially for materials which include either ceramics, polymers, metals, alloys, refractories, carbons and it is very expensive to design and manufacture the experimental setup [16].

\section{EXPERIMENTAL SETUP}

\subsection{Experimental Apparatus}

A schematic diagram of the experimental setup is shown in Fig. 2 and the photographs of the various components are shown in Fig. 3. The schematic diagram and photographs are labelled appropriately and listed in Table 2. The internal diameter of the sample casing is $76.2 \mathrm{~mm}$ and the specimen casing internal height is about $63.5 \mathrm{~mm}$. the samples of any size within $70 \mathrm{~mm}$ diameter and within $60 \mathrm{~mm}$ length can easily be accommodated for testing. The system heat source can operate at a maximum

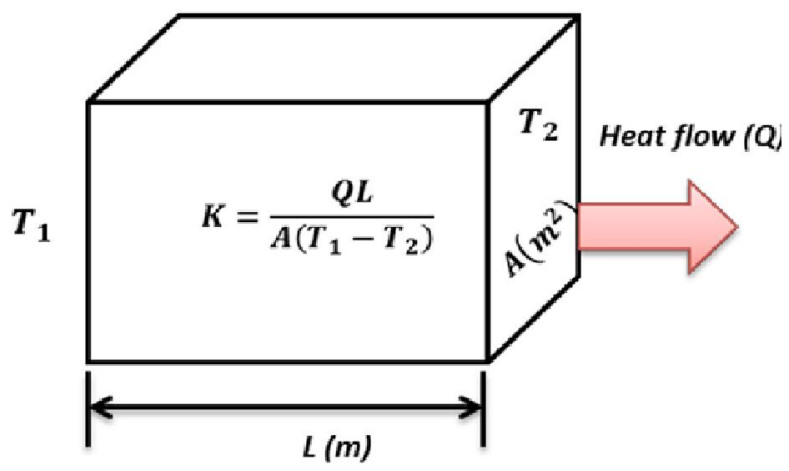

FIG. 1(b). ILLUSTRATION IS THE HEAT TRANSFER MECHANISM 
temperature of $200^{\circ} \mathrm{C}$. The heat sink temperature is maintained through water circulation in the heat sink chamber using a motor as shown in Fig. 2. The system operates at 110 volts AC power supply. The system is provided with the provision of surcharge weight for an appropriate docking. In order to avoid the heat transfer from the sides of the specimen, a vacuum is created inside the chamber through the suction pump. The heat source temperature and heat sink temperature is shown on LCD display. A Complete setup of the experiment in operation mode is shown in Fig. 4.

\subsubsection{Sample Assembling}

The sample of the required size and well-polished (for appropriate docking) is placed on the heat sink plate as shown in Fig. 2. The heat source along with casing is placed on the heat sink chamber with adequate adjustment and clamped using the top platen. The surcharge load is transferred through loading rod and top platen and the system is assembled with clamping screws.

TABLE 1. COMPARISON OF ALL THERMAL CONDUCTIVITY MEASUREMENTS METHODS AND THEIR LIMITATIONS [17]

\begin{tabular}{|c|c|c|c|c|c|c|}
\hline No. & Method & $\begin{array}{l}\text { Temperature } \\
\text { Range }\end{array}$ & $\begin{array}{l}\text { Uncertainty } \\
(\%)\end{array}$ & $\begin{array}{l}\text { Materials to be } \\
\text { Tested }\end{array}$ & Advantages & Disadvantages \\
\hline 1. & Guarded Hot Plate & $80-80^{\circ} \mathrm{K}$ & 2 & $\begin{array}{l}\text { Insulating materials, } \\
\text { plastic and glass, } \\
\text { concrete and soil }\end{array}$ & $\begin{array}{l}\text { High Accuracy, } \\
\text { simple construction } \\
\text { and operation }\end{array}$ & $\begin{array}{l}\text { Longer measurement } \\
\text { times are needed }\end{array}$ \\
\hline 2. & Guard Cylinder & $4-100^{\circ} \mathrm{K}$ & 2 & Metals & $\begin{array}{c}\text { Simultaneous } \\
\text { measurement of } \\
\text { electrical conductivity } \\
\text { of sample and } \\
\text { coefficient } \\
\end{array}$ & $\begin{array}{l}\text { Sufficient time is } \\
\text { required for } \\
\text { measurements }\end{array}$ \\
\hline 3. & Heat Flow Meter & $100-200^{\circ} \mathrm{C}$ & $3-10$ & $\begin{array}{l}\text { Insulating materials, } \\
\text { plastic and glass and } \\
\text { ceramics }\end{array}$ & $\begin{array}{c}\text { Simple } \\
\text { construction, } \\
\text { operation }\end{array}$ & $\begin{array}{l}\text { Measurement } \\
\text { uncertainty } \\
\text { exists }\end{array}$ \\
\hline 4. & Comparative Method & $20-1300^{\circ} \mathrm{C}$ & $10-20$ & $\begin{array}{l}\text { Metals, plastic } \\
\text { and } \\
\text { ceramics }\end{array}$ & $\begin{array}{c}\text { Simultaneous } \\
\text { measurement of } \\
\text { sample and reference } \\
\text { material conductivity }\end{array}$ & $\begin{array}{l}\text { Measurement } \\
\text { uncertainty is high }\end{array}$ \\
\hline 5. & Direct Heating & $400-300^{\circ} \mathrm{K}$ & $2-10$ & Metals & $\begin{array}{l}\text { Simple and fast, } \\
\text { simultaneous } \\
\text { measurement of } \\
\text { electrical } \\
\text { conductivity } \\
\end{array}$ & $\begin{array}{c}\text { Works for only } \\
\text { electrical conducting } \\
\text { materials }\end{array}$ \\
\hline 6. & Pipe Method & $20-2500^{\circ} \mathrm{C}$ & $3-20$ & Solid specimen & $\begin{array}{l}\text { Has a good } \\
\text { temperature range }\end{array}$ & $\begin{array}{c}\text { Longer measurement } \\
\text { time and sample } \\
\text { preparations }\end{array}$ \\
\hline 7. & Hot Wire, Hot Strip & $20-2000^{\circ} \mathrm{C}$ & $1-10$ & $\begin{array}{l}\text { Liquid gases } \\
\text { and } \\
\text { low conductivity } \\
\text { solids }\end{array}$ & $\begin{array}{l}\text { Fast and has good } \\
\text { accuracy and works } \\
\text { at range of } \\
\text { temperature }\end{array}$ & $\begin{array}{l}\text { This is inappropriate } \\
\text { to determine the } \\
\text { conductivity of } \\
\text { anisotropic materials }\end{array}$ \\
\hline 8. & Laser Flash Method & $100-3000^{\circ} \mathrm{C}$ & $3-5$ & $\begin{array}{l}\text { Solids } \\
\text { and } \\
\text { Liquids }\end{array}$ & $\begin{array}{c}\text { Fast, good accuracy } \\
\text { at higher } \\
\text { temperatures, } \\
\text { works good for } \\
\text { most of the solids, } \\
\text { liquids and } \\
\text { powdered } \\
\text { form samples }\end{array}$ & $\begin{array}{l}\text { Very Expensive, } \\
\text { not suitable for } \\
\text { insulation } \\
\text { materials }\end{array}$ \\
\hline
\end{tabular}

Mehran University Research Journal of Engineering \& Technology, Volume 37, No. 4, October, 2018 [p-ISSN: 0254-7821, e-ISSN: 2413-7219] 


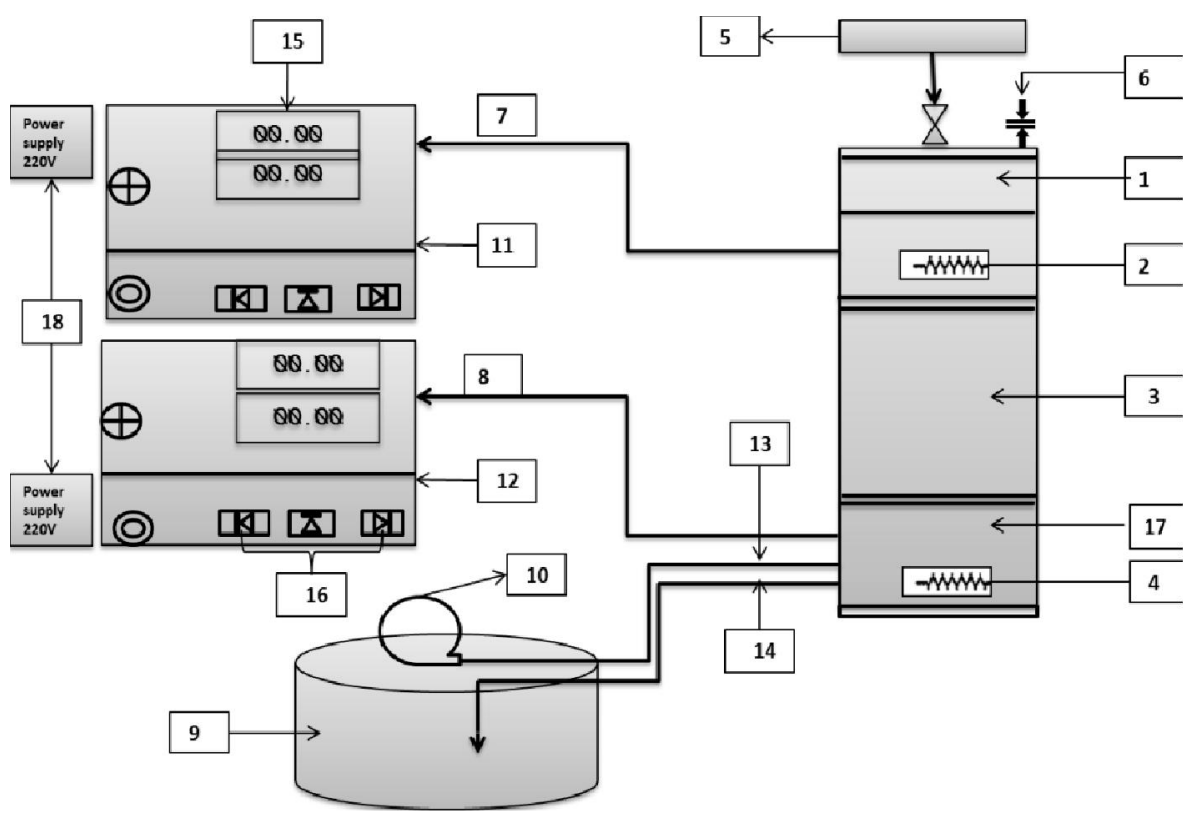

FIG. 2. BASIC EXPERIMENTAL SETUP LAYOUT OF THERMAL CONDUCTIVITY MEASUREMENT APPARATUS
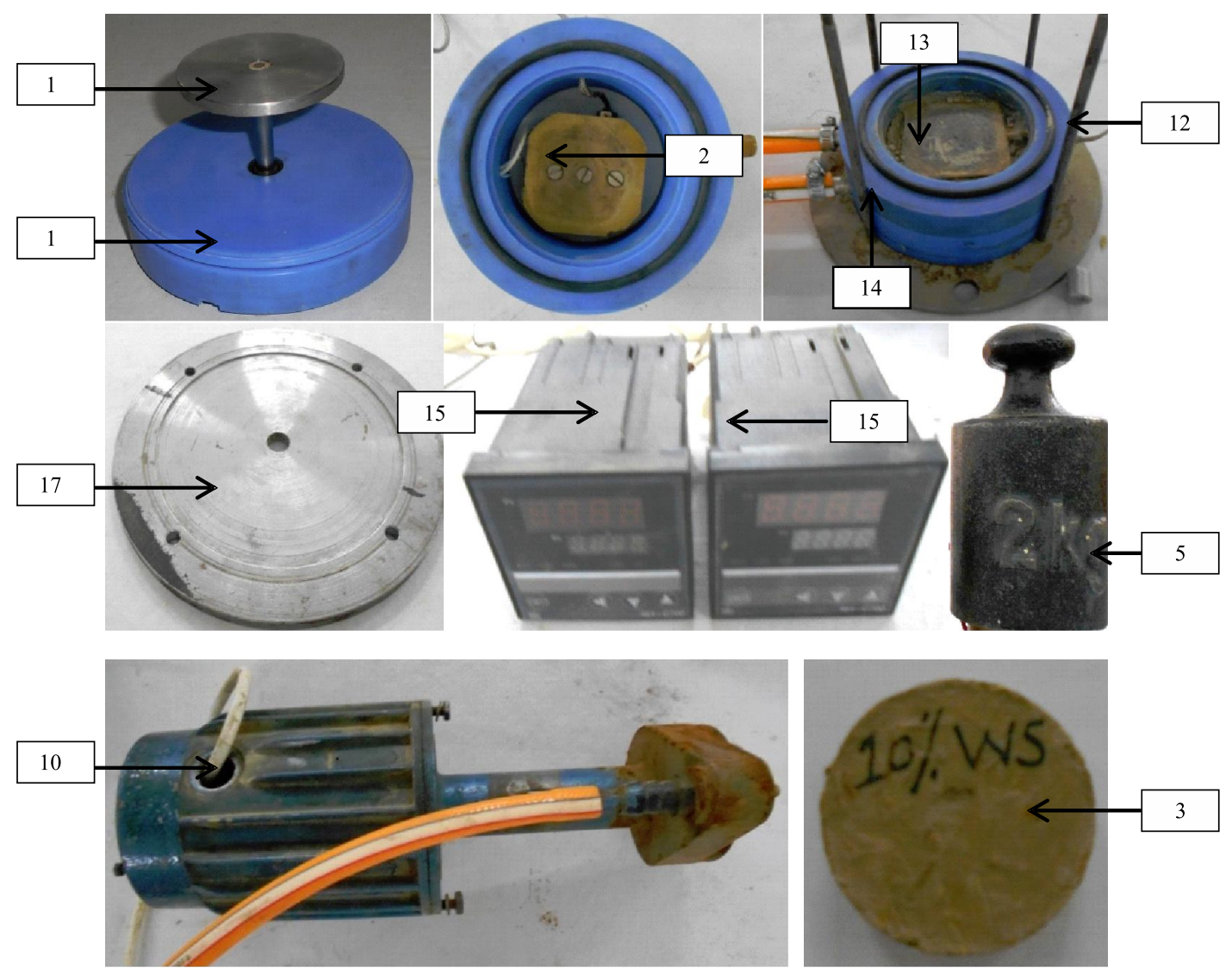

FIG. 3. COMPONENTS OF THE GUARDED HEAT FLOW THERMAL CONDUCTIVITY EXPERIMENTAL SETUP

Mehran University Research Journal of Engineering \& Technology, Volume 37, No. 4, October, 2018 [p-ISSN: 0254-7821, e-ISSN: 2413-7219] 


\subsubsection{Testing procedure}

After completing the system assembly the heat sink water circulation motor is started to keep the heat sink temperature controlled followed by switching on the heat source power supply. The temperatures are displayed on the LCD as shown in Fig. 2. The system is kept running until both heat source and hint sink temperatures are becomes stable. The readings are taken once the temperatures become stable.

Data Collection and Calculations: The following readings are taken for the determination of thermal conductivity of the material:

$\mathrm{Q}=$ The amount of heat energy (Watts)

$\mathrm{T} 1=$ Heat source temperature $\left({ }^{\circ} \mathrm{C}\right.$ or $\left.\mathrm{K}\right)$

$\mathrm{T} 2=$ Heat sink temperature $\left({ }^{\circ} \mathrm{C}\right.$ or $\left.\mathrm{K}\right)$

$A=$ Area cross-section of the specimen $\left(\mathrm{m}^{2}\right)$

$\mathrm{L}=$ Sample thickness (m)

The coefficient of thermal conductivity (K) can be determined by applying Equation (3)

$\mathrm{K}=\frac{\mathrm{QL}}{\mathrm{A} \Delta \mathrm{T}}$

\section{CALIBRATION OFTHE SETUP}

The calibration and accuracy of the conductivity measuring device are done by performing the tests on standard samples of known conductivity. The calibration setup is shown in Fig. 5 and the calibration chart developed is shown in Fig. 6.

\section{TYPICAL TRIAL TESTS}

\subsection{Sample Preparation}

In the present study clayey soil was used as a base material; while lime and wheat straw were used as soil

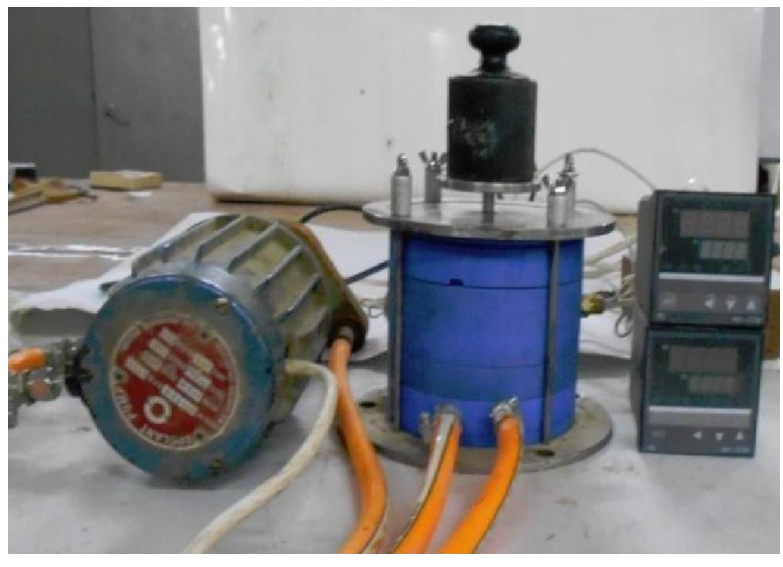

FIG. 4. SCHEMATIC REPRESENTATION OF THE THERMAL CONDUCTIVITY DEVICE IN OPERATION

TABLE 2. COMPONENTS OF THERMAL CONDUCTIVITY SETUP

\begin{tabular}{|c|c|c|c|}
\hline \multicolumn{4}{|c|}{ Components } \\
\hline 1. & Top plate & 10. & Pump to discharge fluid for circulation \\
\hline 2. & Upper Thermocouple heating coils & 11. & Upper-temperature sensor \\
\hline 3. & Soil sample & 12. & Lower temperature sensor \\
\hline 4. & Lower Thermocouple heating coils & 13. & Fluid Inlet pipe \\
\hline 5. & Surcharge weight & 14. & Fluid outlet pipe \\
\hline 6. & Power 110 Voltage & 15. & Control switch \\
\hline 7. & Upper-temperature sensor wire & 16. & Lower plate \\
\hline 8. & Lower temperature sensor wire & 17. & Power supply [220 Voltage] \\
\hline 9. & Cooling bath & 18. & \\
\hline
\end{tabular}

Mehran University Research Journal of Engineering \& Technology, Volume 37, No. 4, October, 2018 [p-ISSN: 0254-7821, e-ISSN: 2413-7219] 
modifying/stabilizing agents. The required amount of clayey soil was collected by breaking the lumps and passing it through No. 40 sieve. Remoulded samples were prepared by adding the requiredquantity of lime and wheat straw. For thermal and electrical conductivity testing; samples of size, $50 \mathrm{~mm}$ diameter and $20 \mathrm{~mm}$ thickness were prepared by adding varying percentages of lime and

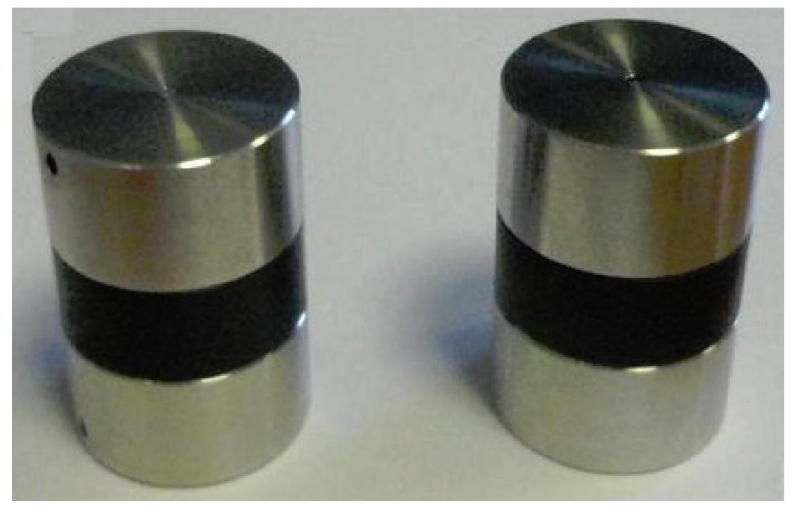

FIG. 5. CALIBRATION REFERENCE MATERIAL

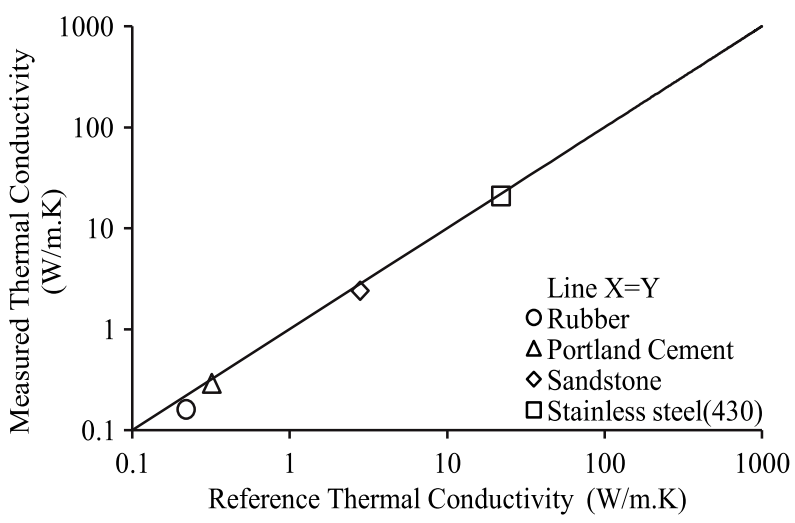

FIG. 6. PLOT IS THE MEASURED AND REFERENCED THERMAL CONDUCTIVITY VALUES wheat straw. Samples were dry-mixed prior to the addition of water. The samples were then soaked and subsequently, oven dried at $105 \pm 5^{\circ} \mathrm{C}$ for 24 hours prior to the thermal and electrical conductivity experiments.

\section{RESULTS AND DISCUSSION}

A variety of tests were conducted on different materials. Typical results of some of the tests conducted on clayey samples are presented below:

Clayey samples added with the various percent of wheat straw are shown in Fig. 7. All samples were prepared by dry mixing the soil with the requiredpercent of wheat straw and thereafter added with water to prepare a workable paste. The samples were sun dried for a week. The sundried samples were oven dried before thermal conductivity tests. The tests results are given in Table 3.The effect of wheat straw on the thermal conductivity

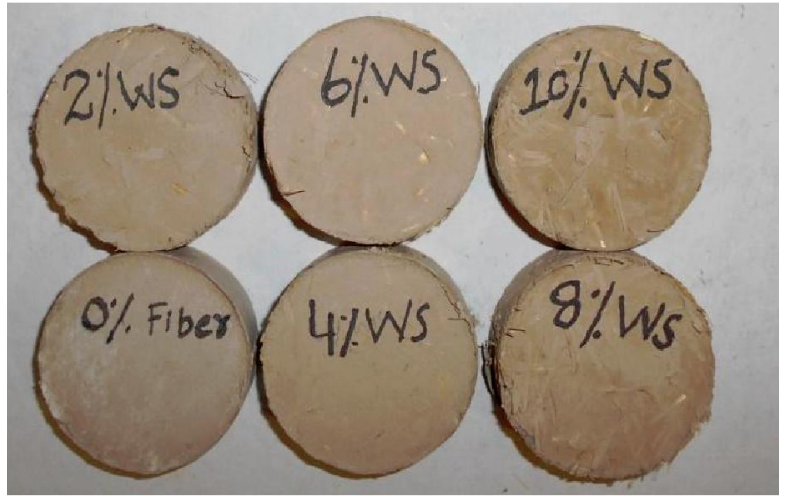

FIG. 7. CLAYEY SAMPLE MIXED WITH WHEAT STRAW

TABLE 3. EFFECT OF WHEAT STRAW CONTENT ON THERMAL CONDUCTIVITY/ RESISTIVITY

\begin{tabular}{|c|c|c|c|c|c|c|c|c|c|}
\hline $\begin{array}{c}\text { Wheat } \\
\text { Straw } \\
(\%)\end{array}$ & $\begin{array}{c}\text { Heat Flow } \\
\mathrm{Q} \\
\text { Watt } \\
(\mathrm{W})\end{array}$ & $\begin{array}{c}\text { Thickness } \\
\Delta \mathrm{x}(\mathrm{mm})\end{array}$ & $\begin{array}{c}\text { Diameter } \\
(\mathrm{mm})\end{array}$ & $\begin{array}{c}\text { Area } \\
(\mathrm{mm})\end{array}$ & $\begin{array}{c}\text { Heat source } \\
\text { Temperature } \\
\text { Th }\left({ }^{\circ} \mathrm{C}\right)\end{array}$ & $\begin{array}{c}\text { Heat Sink } \\
\text { Temperature } \\
\mathrm{Ts}\left({ }^{\circ} \mathrm{C}\right)\end{array}$ & $\begin{array}{c}\text { Change in } \\
\text { Temperature } \\
\Delta \mathrm{T}\left({ }^{\circ} \mathrm{K}\right) \text { or } \\
\left({ }^{\circ} \mathrm{C}\right)\end{array}$ & $\begin{array}{c}\text { Thermal } \\
\text { Conductivity } \\
\lambda(\mathrm{W} / \mathrm{m} . \mathrm{K})\end{array}$ & $\begin{array}{c}\text { Thermal } \\
\text { Resistivity } \\
(\mathrm{m} . \mathrm{K} / \mathrm{W})\end{array}$ \\
\hline 0 & 17 & 14.15 & 47.64 & 1782.75 & 136 & 44 & 92 & 1.466 & 0.682 \\
\hline 2 & 17 & 15.22 & 48.08 & 1816.06 & 150 & 43 & 107 & 1.332 & 0.751 \\
\hline 4 & 17 & 15.5 & 48.67 & 1860.67 & 155 & 42 & 113 & 1.253 & 0.798 \\
\hline 6 & 17 & 14.73 & 49.14 & 1896.55 & 157 & 45 & 112 & 1.179 & 0.848 \\
\hline 8 & 17 & 15.75 & 49.37 & 1914.34 & 173 & 46 & 127 & 1.102 & 0.908 \\
\hline 10 & 17 & 15.27 & 49.56 & 1929.57 & 166 & 44 & 122 & 1.103 & 0.907 \\
\hline
\end{tabular}

Mehran University Research Journal of Engineering \& Technology, Volume 37, No. 4, October, 2018 [p-ISSN: 0254-7821, e-ISSN: 2413-7219] 
and thermal resistivity are shown in Figs. 8-9 respectively. From the experimental results, it may be seen that there is a gradual decrease in the thermal conductivity and increase in the thermal resistivity due to the increase in the wheat straw content.

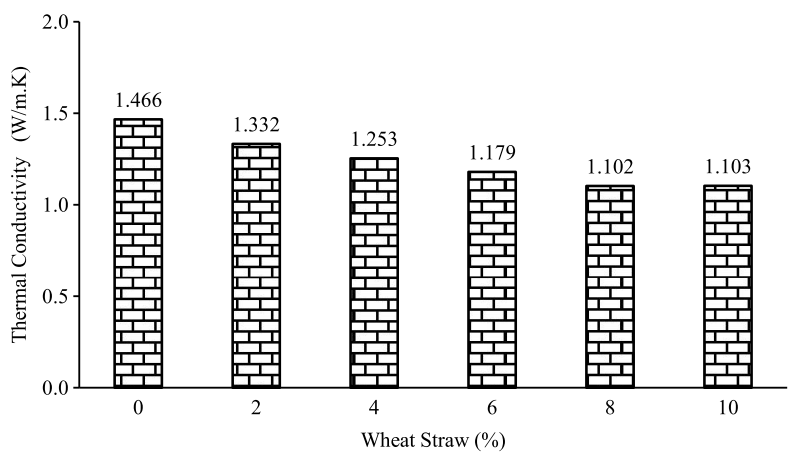

FIG. 8. EFFECT OF WHEAT STRAW ON THE THERMAL CONDUCTIVITY

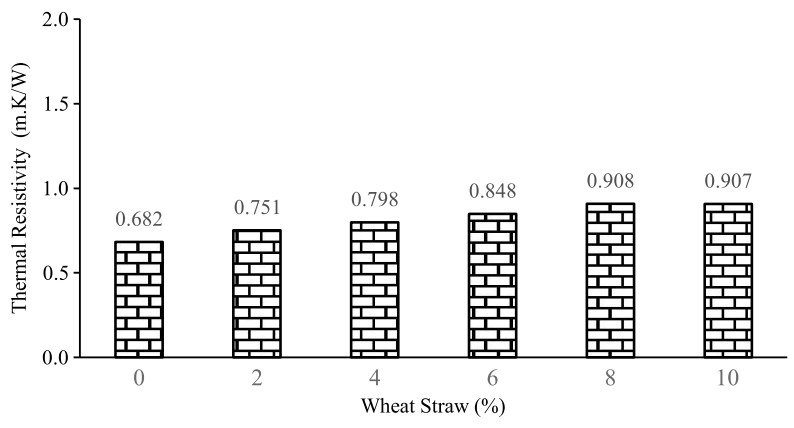

FIG. 9. EFFECT OF WHEAT STRAW ON THE THERMAL RESISTIVITY
Similarly, the effect of lime on the thermal conductivity/ resistivity of clayey soil was also examined. The samples were prepared by dry mixing the lime with clayey soil and thereafter added with water to prepare workable pastes. The samples were then sun-dried for a week and oven dried before testing. The samples prepared with the various percent of lime added in the clayey soil are shown in Fig. 10. The results are given in Table 4.The effect of lime on the thermal conductivity and thermal resistivity are shown in Figs. 11-12 respectively. From Figs. 11-12 it can be seen that there is a decrease in the thermal conductivity and increase in the thermal resistivity of clayey soils due to the increase in the lime content. The comparison of the effect of lime and wheat straw on the thermal conductivity of clayey soils is shown in Fig. 13. From Fig. 13 it can be seen that both lime and wheat straw resulted to decrease in the thermal conductivity; however, the effect of wheat straw is dominant as compared to the effect of lime on the thermal conductivity characteristics, which could be because of the low specific density of wheat straw as compared to the lime. It is also reported in [18-19] that the thermal conductivity is decreasing as the density is decreasing [19] performed thermal conductivity experiments on Hemp shiv mixed with clay and found that the addition of Hemp shiv resulted to the lowest thermal conductivity due to the low-density samples.

TABLE 4. EFFECT OF LIME CONTENT ON THERMAL CONDUCTIVITY/ RESISTIVITY

\begin{tabular}{|c|c|c|c|c|c|c|c|c|c|}
\hline $\begin{array}{c}\text { Lime } \\
(\%)\end{array}$ & $\begin{array}{c}\text { Heat Flow } \\
\mathrm{Q} \\
\text { Watt } \\
(\mathrm{W})\end{array}$ & $\begin{array}{c}\text { Thickness } \\
\Delta \mathrm{x}(\mathrm{mm})\end{array}$ & $\begin{array}{c}\text { Diameter } \\
(\mathrm{mm})\end{array}$ & $\begin{array}{c}\text { Area } \\
(\mathrm{mm})\end{array}$ & $\begin{array}{c}\text { Heat source } \\
\text { Temperature } \\
\mathrm{Th}\left({ }^{\circ} \mathrm{C}\right)\end{array}$ & $\begin{array}{c}\text { Heat Sink } \\
\text { Temperature } \\
\mathrm{Ts}\left({ }^{\circ} \mathrm{C}\right)\end{array}$ & $\begin{array}{c}\text { Change in } \\
\text { Temperature } \\
\Delta \mathrm{T}\left({ }^{\circ} \mathrm{K}\right) \text { or } \\
\left({ }^{\circ} \mathrm{C}\right)\end{array}$ & $\begin{array}{c}\text { Thermal } \\
\text { Conductivity } \\
\lambda(\mathrm{W} / \mathrm{m} . \mathrm{K})\end{array}$ \\
\hline 0 & 17 & 14.15 & 47.64 & 1782.75 & 136 & 44 & 92 & $\begin{array}{c}\text { Resistivity } \\
(\mathrm{m} . \mathrm{K} / \mathrm{W})\end{array}$ \\
\hline 2 & 17 & 15.48 & 48.44 & 1843.35 & 149 & 44 & 105 & 1.466 & 0.682 \\
\hline 4 & 17 & 16.04 & 49.08 & 1892.15 & 151 & 46 & 105 & 1.373 & 0.728 \\
\hline 6 & 17 & 16.25 & 48.77 & 1868.55 & 161 & 46 & 115 & 1.286 & 0.778 \\
\hline 10 & 17 & 15.67 & 48.88 & 1876.99 & 155 & 46 & 109 & 1.302 & 0.768 \\
\hline
\end{tabular}

Mehran University Research Journal of Engineering \& Technology, Volume 37, No. 4, October, 2018 [p-ISSN: 0254-7821, e-ISSN: 2413-7219] 


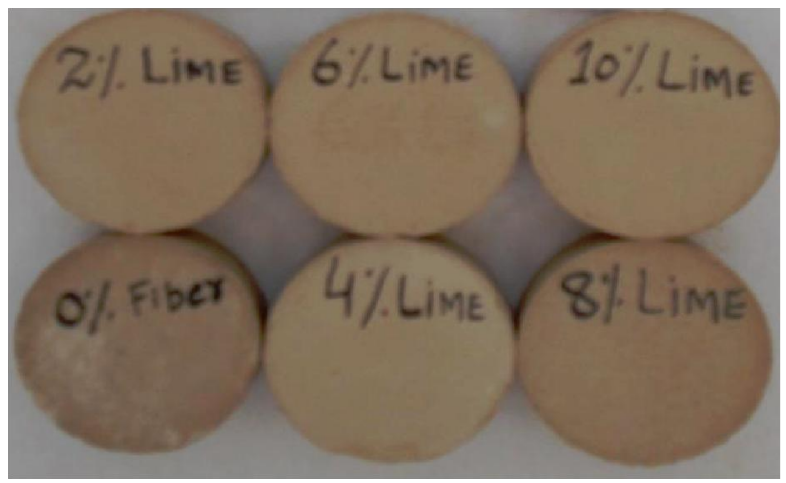

FIG.10. CLAYEY SAMPLE MIXED WITH LIME

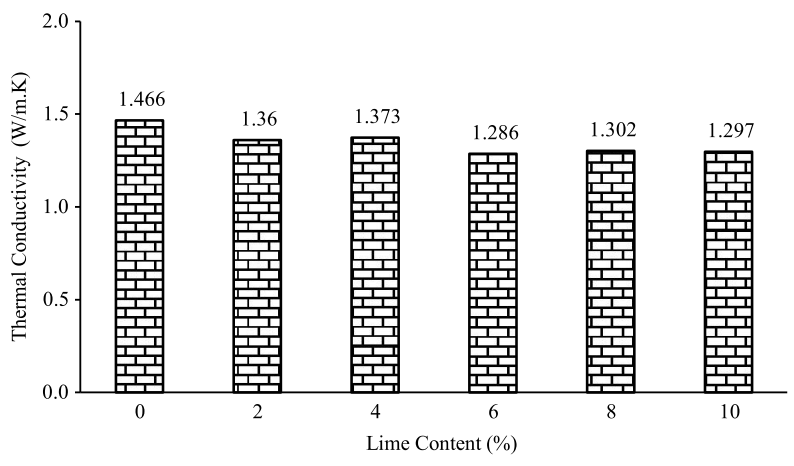

FIG. 11. EFFECT OF LIME ON THE THERMAL CONDUCTIVITY

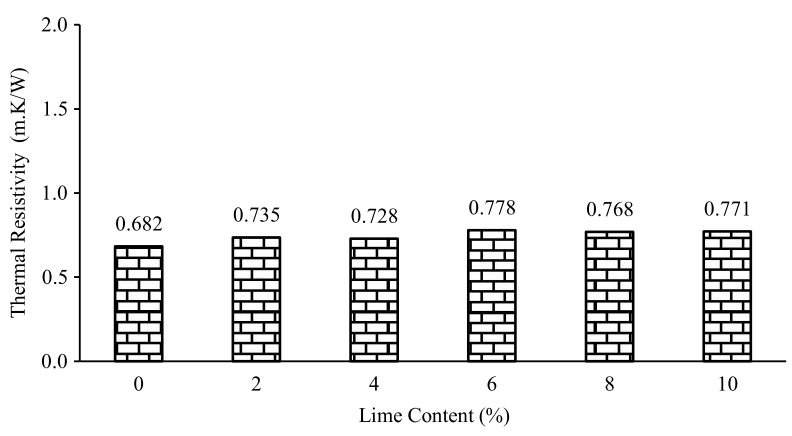

FIG. 12. EFFECT OF LIME ON THE THERMAL RESISTIVITY

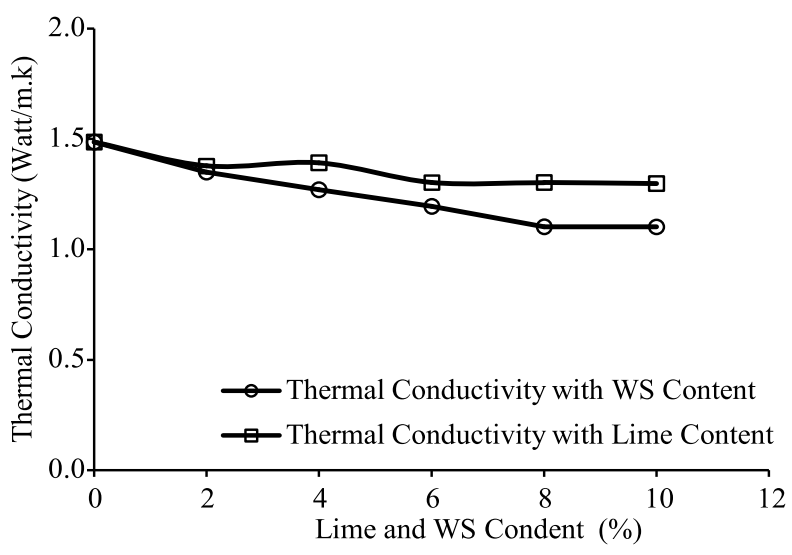

FIG. 13. EFFECT OF LIME AND WHEAT STRAW CONTENT ON THE THERMAL CONDUCTIVITY OF SOIL

\section{CONCLUSION}

"The present TCM (Thermal Conductivity Meter) is an indigenously developed experimental setup; its results have been validated and calibrated with reference materials of known conductivity. The setup is capable of testing a wide range of materials; such as soil, rock, cemented materials, un-cemented materials, undisturbed samples and remoulded samples. Varying size of the samples ranging from 10-100 mm thickness and 36-140 $\mathrm{mm}$ diameter can be tested. The setup can easily be operated and optimized with relatively low operating and maintenance cost.

From the results of the trial tests conducted through present experimental setup, it can be concluded that there is a decrease in the thermal conductivity of clayey soils added with lime or wheat straw. i.e. $10 \%$ addition of lime and wheat straw resulted to decrease in the thermal conductivity of clayey soils by 12.7 and $25.8 \%$ respectively.

\section{ACKNOWLEDGEMENT}

The authors are grateful to the NED University of Engineering \& Technology, Karachi, Pakistan, for support provided towards the fabrication facilities.

\section{REFERENCES}

[1] Kidalov, S.V., and Shakhov, F.M., "Thermal Conductivity of Diamond Composites", Materials, Volume 2, No. 4, pp. 2467-2495, 2009.

Tritt, T.M., and Weston, D., "Measurement Techniques and Considerations for Determining Thermal Conductivity of Bulk Materials", Thermal Conductivity, pp. 187-203, Springer, 2004.

\begin{abstract}
Zhao, D., Qian, X., Gu, X., Jajja, S.A., and Yang, R., "Measurement Techniques for Thermal Conductivity and Interfacial Thermal Conductance of Bulk and Thin Film Materials", Journal of Electronic Packaging, Volume 138, No. 4, pp. 40802, 2016.
\end{abstract}


[4] Ochsner, T.E., Horton, R., and Ren, T., "A New Perspective on Soil Thermal Properties", Soil Science Society of America Journal, Volume 65, No. 6, pp. 1641-1647, 2001.

Peavy, B., "A Heat Transfer Note on Temperature Dependent Thermal Conductivity", Journal of Building Physics, Volume 20, No. 1, pp. 76-90, 1996.

[6] Fenollera, M., Míguez, J.L., Goicoechea, I., and Lorenzo, J., "Experimental Study on Thermal Conductivity of Self-Compacting Concrete with Recycled Aggregate", Materials, Volume 8, No. 7, pp. 4457-4478, 2015.

Kim, K.-H., Jeon, S.-E., Kim, J.-K., and Yang, S., “An Experimental Study on Thermal Conductivity of Concrete", Cement and Concrete Research, Volume 33, No. 3, pp. 363-371, 2003.

Handbook, A.F., "American Society of Heating, Refrigerating and Air-Conditioning Engineers", Inc.Atlanta, GA, USA,2009.

Gustafsson, S.E., “Transient Plane Source Techniques for Thermal Conductivity and Thermal Diffusivity Measurements of Solid Materials", Review of Scientific Instruments, Volume 62, No. 3, pp. 797-804, 1991.

[10] Usowicz, B., Lipiec, J., Usowicz, J.B., and Marczewski, W., "Effects of Aggregate Size on Soil Thermal Conductivity: Comparison of Measured and ModelPredicted Data", International Journal of Heat and Mass Transfer, Volume 57, No. 2, pp. 536-541, 2013.

[11] Machrafi, H., and Lebon, G., "Size and Porosity Effects on Thermal Conductivity of Nanoporous Material with an Extension to Nanoporous Particles Embedded in a Host Matrix", Physics Letters-A, Volume 379, No. 12, pp. 968-973, 2015.
Alam, M.T. "Size Effects on Mechanical and Thermal Properties of Thin Films", The Pennsylvania State University, 2015.

[13] Abu-Hamdeh, N.H., "Thermal Properties of Soils as Affected by Density and Water Content", Biosystems Engineering, Volume 86, No. 1, pp. 97-102, 2003.

[14] Bergman, T.L., and Incropera, F.P., "Introduction to Heat Transfer", John Wiley \& Sons, 2011.

[15] Yüksel, N., “The Review of Some Commonly Used Methods and Techniques to Measure the Thermal Conductivity of Insulation Materials", Insulation Materials in Context of Sustainability, 2016.

[16] Presley, M.A., and Christensen, P.R., "Thermal Conductivity Measurements of Particulate Materials2 Results", Journal of Geophysical Research, Volume 102, No. E3, pp. 6551-6566, Planets, 1997.

[17] Buck, W., and Rudtsch, S., "Thermal Properties", Springer Handbook of Materials Measurement Methods, pp. 399-429, Springer, 2006.

[18] Nguyen, T.T., Picandet, V., Carre, P., Lecompte, T., Amziane, S., and Baley, C., "Effect of Compaction on Mechanical and Thermal Properties of Hemp Concrete", European Journal of Environmental and Civil Engineering, Volume 14, No. 5, pp. 545-560, 2010.

[19] Mazhoud, B., Collet, F., Pretot, S., and Lanos, C., "Development and Hygric and Thermal Characterization of Hemp-Clay Composite", European Journal of Environmental and Civil Engineering, pp. 1-11, 2017. 